\title{
Tūhono Māori: A Research Study of Attachment from an Indigenous Māori Perspective
}

\author{
Alayne Mikahere-Hall \\ Taupua Waiora Research Centre, Auckland
}

\section{Whakarāpopotonga}

He wānanga rangahau ine kounga mahitahi i te taha o te hakune me te huarahi Kaupapa Taketake Māori. Ko tōna pūtaketanga ko te whakawā i te tino āhukahukatanga Māori mō te mōhio i te āhua whakatairanga hononga hauora whānau i waenga i te pūnaha hāpori Mãori. E titiro ana te rangahau ki te hāpai i ō mātau mōhio mō te hononga hauora mai i tā te tirohanga Māori; tūhuratanga ariā hononga taketake ariā hononga hou whāngaihanga herenga hauora kare-ā-roto, whakatenatenahanga herenga whānau whita. Ko te whāinga à tēnei rangahau ko te whakawhanake aria kaupapa Māori hai whakaauaha kōkuhu pānuiwhetuki mō ngā tamariki Māori me ō rātau whānau. Ko te takunetanga à tēnei wānanga he tauāki i te āputa mātauranga e whakapaehia ana nei he hononga ariā hou te tūhono me ōna ariā tūhonotanga. E matapakihia ana te hakunetanga me te huarahi whakamāhia i roto i te wānanga rangahau Tūhono Māori.

\begin{abstract}
Tūhono Māori is a qualitative research project that engages with Indigenous Kaupapa Māori methodology and methods. The purpose is to investigate a uniquely Māori approach for understanding the nature in which healthy whānau (family) relationships are fostered within a Māori social system. The research seeks to advance what we understand about healthy attachments through an Indigenous Māori lens, exploring traditional and contemporary notions of attachment in which healthy emotional bonds are fostered and secure whānau attachments promoted. The aim of this research is to develop Māori theory that will shape trauma-informed interventions for Māori children and their whānau. The study is intended to address a knowledge gap in which tūhono (attach/bond) and related concepts such as tūhonotanga (attachment/connectedness) are proposed as a contemporary Māori notion of attachment. This paper discusses the methodology and methods employed in the Tūhono Māori research project.
\end{abstract}

\footnotetext{
Mikahere-Hall, A. (2019). Tūhono Māori: A research study of attachment from an Indigenous Māori perspective. Ata: Journal of Psychotherapy Aotearoa New Zealand, 23(1), 61-76. https://doi.org/10.9791/ ajpanz.2019.07
} 
Keywords: tūhono (attach/bond), attachment, tamariki (children), Kaupapa Māori, Indigenous methodology

\section{Introduction}

Indigenous research methodologies (Eketone, 2008; Lee, 2009; Louis, 2007; Sherwood, 2010; L. T. Smith, 2013; Smith, Maxwell, Puke, \& Temara, 2016;) are helping to transform the research environment and their respective disciplines in search of affirmative evidencebased solutions. Tūhono Māori is a culture-specific research project, funded by the Health Research Council of New Zealand, that is currently investigating attachment from a Māori worldview. There is a scarcity of Māori research that focuses on Māori children and their attachment development. Consequently, there have been limited Māori-led research initiatives that provide a theoretical and cultural perspective of secure attachment (Fleming, 2018; Hall, 2015). Nevertheless, the issue of attachment is not absent from Māori understanding; it is however described according to our own language and cultural ideology and with a focus on whānau inter-connectedness. Tūhono Māori embodies key principles that relate to being Māori and integrates cultural values and ideas to understand attachment from Te Ao Māori (the Mãori world). This health research is interested in solutions that respond to unresolved trauma that have spiritual, physical, emotional, psychological and long-term mental health impacts.

The terms tamariki (children) and mokopuna (grandchildren) are used interchangeably throughout this paper. Mokopuna tamariki Māori (Māori grandchildren and children) acknowledges the important link the tamaiti (child) has with mātua tūpuna (grandparents) and immediate whānau.

\section{Baseline Concepts}

Tūhono Māori focuses on whānau and the relationship of parents with the child but does not dismiss the importance of the mother-child dyad or a central parenting figure. Tühono Māori expands the focus toward the whānau, to the hapu (sub-tribe), and to the community of people who support a māmā (mother) and her pēpi (baby) to thrive.

The concept of tūhono as the basis for a Māori understanding of attachment grew out of my $\mathrm{PhD}$ work, in which I engaged in a number of conversations and consultations both with my own whānau and with wider whānau. These conversations were meaningful and important in forming the foundations to ensure Māori terminology and concepts were consistent with mātauranga Māori (Māori knowledge) and Māori perspectives of attachment. Several inter-related concepts emerged, including tūhono to convey the notion of the intimate personal, emotional, and psychological bond; tūhonotanga to capture the interconnected relationships between whānau, hapū and iwi; tūhonohono and hononga to understand the formation of connections and bonds. The Māori and Indigenous advisory committee members supporting this research also gave their support for the conceptual ideology that underpins the Tūhono Māori study.

There are a number of existing Māori initiatives that promote tūhono as a concept to connect and keep whānau, hapū and iwi bonded and linked to each other. The Tūhono Trust, 
a web-based initiative to promote whānau, hapū and iwi engagement and Te Rōpū Tūhono, an iwi initiative to promote Ngāpuhi engagement on issues related to topical and important matters are but two examples.

\section{Ethical Approval}

Ethical approval was granted by the Auckland University of Technology Ethics Committee (AUTEC) on 10 January 2018. The ethics application considered important Mãori research principles as set out in Te Ara Tika (Hudson, Milne, Reynolds, Russell \& Smith, 2010). The principles helped to inform and guide participant recruitment and data collection processes in an acceptable manner, from both cultural and health research perspectives. The principles are values-based and embody manaakitanga (care) to guide the quality and structure of the processes from which engagement between researcher and research participant unfolds.

\section{Research Design}

Research tools such as consent forms and participant information sheets are common to social science research and research generally. These tools have their origins in Western research methods, and for the sake of pragmatism, common language and ethical requirements they serve a useful purpose. Māori researchers have critiqued these methods for their appropriateness and developed their own (Cram \& Kennedy, 2010). The research tools for the Tūhono Māori study were chosen so as not to distract from the Māori epistemology the study encompasses.

A qualitative Kaupapa Māori research design grounds the research on mātauranga Māori (Māori knowledge), to privilege Māori cultural norms and to capture the lived realities of Māori from a culturally informed position. Therefore, it is important that this research embodies key principles that are related to being Māori, that validate te reo Māori me ōnā tikanga (the Māori language and values) and is concerned with the holistic and cultural wellbeing of Māori (G.H. Smith, 2012).

The research design includes three research participant domains; key informants $(n=6)$ for specialist knowledge, kaumātua-kuia (elders) $(n=6)$ for traditional knowledge, and whānau-hapū constellations $(n=25)$ for inter-personal knowledge. Given the potential size and network of people involved in a whānau-hapu interview the research design limits the interviews to twenty-five constellations with the recruitment of up to eight whānau members participating in each interview. The inclusion of more than eight members is negotiated with whānau to enable enough flexibility for whānau to be sufficiently represented in the interviews. The number of whānau members recruited allows for intergenerational experience and scope. Overseeing the management of interviews ensures that the overall data collection and data analysis fits within the capability of the research project.

The research is not intended to privilege any specific whānau, hapū, or iwi and is anticipated to capture data that will highlight vital knowledge specific to concepts related to tūhono and tūhonotanga. There are three main considerations in the Tūhono Māori study; characterising whānau, establishing safety criteria, and principles of engagement. 


\section{Characterising Whānau}

In order to determine what constitutes a whānau collective (Cram \& Kennedy, 2010), certain characteristics were identified to quantify what is meant by contemporary whānau. This was a necessary first step for two principal reasons. First, to establish the benchmark for people represented as potential research participants. Second, to evaluate the likely benefits of respective participants and their potential to contribute to one of three participant domains used in the study. Nurturing and fostering secure attachments for mokopuna Māori involves interpersonal relationships where whānau tiaki (protect,look after) tamariki and mokopuna through their formative years. Whakapapa (genealogy) and whanaungatanga (shared relationships) are core features of a whānau and of Māori social structure. Whānau, whakapapa and whanaungatanga are critical features of this study.

Whakapapa involves a network of biological connections, and it is through birth one can claim belonging to their immediate whānau. Whanaungatanga is a relatedness process for making connections with extended relatives. Knowing one's whakapapa helps to determine who belongs within the whānau system and who does not. The whānau unit is the smallest of the Māori social system, and can include three, four, and in some circumstances five generations. Each whānau unit is both similar due to shared whakapapa, and varied through marriages, migration and division (Moeke-Pickering, 1996). New generations increased the number of whānau units and over time multiplied to form hapū. Similarly, hapū increased to form an amalgamation of extended relationships culminating in the formation of iwi. Whakapapa provides the basis in which kin structures and relationships are organised and maintained. Connections are encouraged within the whānau and hapū, providing a valuable social support system.

Whāngai (foster) is a whānau practice that provides for an additional level of care for children and support for birth parents. The whāngai child-care arrangement is promoted within the confines of the whānau-hapu and when necessary within the wider iwi. This is to ensure that the child and their birth whannau maintain connections to each other and affiliations to their customary practices and hereditary rights, without the impedance of a closed adoption process. Whāngai whānau (the foster family) assume all the responsibilities involved with raising and nurturing a child.

Contemporary whānau are living rurally and in urban centres. Whānau engage with communication technology, modern transportation and the availability of communitybased support systems such as early childhood centres and kōhanga reo (Māori language preschool). Contemporary whānau have evolved in response to colonisation, social trends, and adaptation over time, and these lifestyle adjustments have influenced the organisation of the whānau structure. Extended whānau networks can be both whakapapa related and kaupapa (purpose) related. Kaupapa whānau provide additional support toward a common purpose or goal and can be made up of whānau, friends and colleagues (Lawson-Te Aho, 2010). Current literature indicates that whānau organisation centres around both traditional whakapapa whānau and contemporary kaupapa whānau (Cram \& Kennedy, 2010; M. H. Durie, 1995; Lawson-Te Aho, 2010; Moeke-Pickering; 1996). What has happened in the past and what happens in whānau today will shape the home and world our mokopuna will grow up in (Durie, 2016). Informed by the literature Statistics New Zealand (2013) developed Te Kupenga, which recognises both whakapapa and kaupapa whānau as valid measures of what 
constitutes whānau, where individuals determine their own whānau. The current study is mindful that individuals identify their own whānau by determining the people who are responsible for providing safe fundamental care for mokopuna Māori. The research design appreciates that a Māori caregiving system can be multilevel and multigenerational where whānau and hapū relationships help to foster mokopuna Māori as well as supporting parents, grandparents, siblings, aunts and uncles.

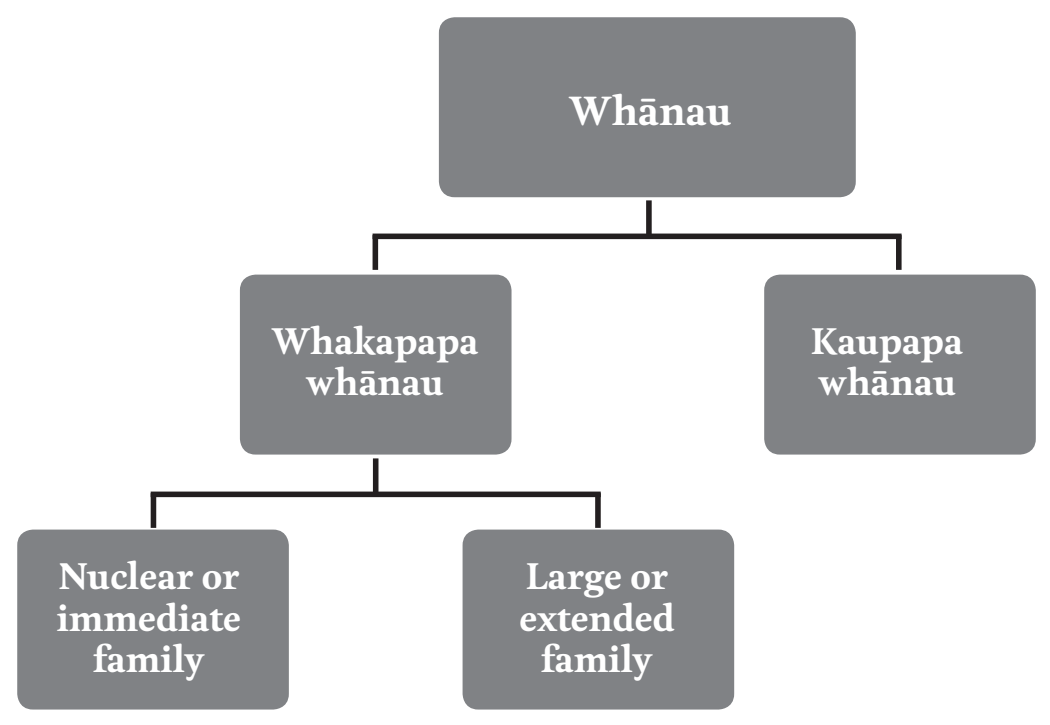

Figure 1. Te Kupenga model of Whānau (Statistics NeW Zealand, 2013)

\section{Establishing Safety Criteria}

This research appreciates that whakapapa and whanaungatanga are valuable intrinsic tāonga (gifts) that come with cultural, social and ethical responsibilities (Hudson et al., 2010). The concept of whakapapa can be far-reaching, extending beyond the biological and hereditary aspects of people - this aspect is discussed later in this paper. The Tūhono Māori study does not assume that everyone in the whānau and hapū system are safe and available caregivers for tamariki and mokopuna Māori. Tūhono Māori is premised on the under-standing that whānau recognise who the consistently reliable and sensitively responsive caregivers are within the whannau system. This is to safeguard against the assumption that the tamaiti (child) can have everyone and yet no one (personal communication, Durie, 1 July 2016).

Safe tikanga values and practices guide the nature in which the researchers and research participants participate in this study. The guiding Mãori principles include tika (correctness), pono (integrity) and aroha (compassion). Rangatiratanga (leadership), manaakitanga (respectful regard), kaitiakitanga (guardianship) and wairuatanga (spirituality) are also embraced as respected Māori ethical principles that are fundamental to this Kaupapa Māori 
research project. Establishing safety criteria as a protective measure involved the inclusion of tikanga in kaitiakitanga confidentiality agreement forms for whānau participants and members of the research team. The intention was to create a research environment promoting cultural values that are meaningful to Māori. Tika, pono and aroha are reciprocal in nature and integral to respectful relationships. It was also important to identify high-risk behaviours to help ascertain if potential research whānau were providing safe home environments for mokopuna Māori. A safety screening questionnaire was developed along with inclusion and exclusion criteria to help determine the safety and eligibility of potential research participants.

\section{INCLUSION AND EXCLUSION CRITERIA}

When considering the parameters of what constitutes a healthy functioning whānau Durie's (2006) three-level framework for measuring Māori wellbeing was taken into account. The safety screening questionnaire developed for this research highlighted the inclusion and exclusion criteria. The safety screening questionnaire is administered prior to the commencement of interviews and also included in the participant information forms.

Inclusion criteria:

- Research participants will have first-hand knowledge and experiences of parenting and responsibilities for providing basic and essential care to dependent children and mokopuna Māori.

- Research participants must be 16 years or older as legally recognised caregivers of dependent children and be able to give written informed consent.

Exclusion criteria:

- Persons deemed high risk or unfit by law to care for children as detailed in the Vulnerable Children's Act, New Zealand Government, 2014.

- The research team recognise the vulnerabilities of mokopuna Mãori where high rates of family violence and addiction difficulties have the potential to distort perceptions and increase risks to children - something that can be normalised in some whānau.

- For reasons of child safety and to help ascertain whether whānau meet the criteria as healthy whānau, a research participant-screening questionnaire is administered to exclude any potential high-risk participants from the research.

The exclusion is necessary to mitigate against the probability that potential research participants do not pose a significant risk to the well-being of children and mokopuna Māori. The safety of mokopuna Māori is paramount to whānau, hapū, iwi and the aims of this research study.

\section{Principles of Engagement}

Pohatu's (2013) Ata principles assist as a guide for planning, participant recruitment, data collection, and data analysis, where respectful engagement with whānau and their family pūrākau (narratives) are fundamental. The principles of Ata consider the research environment 
and the research process as this unfolds. They encourage researcher conduct and behaviour that has a special regard for people in their places and spaces, where respectfulness, reciprocity and the ability to reflect upon personal transformations that occur between the researcher and the research participants. The research project is committed to upholding and fostering a manaenhancing (Ruwhiu et al., 2009) research environment for all who participate within it.

\section{Methodology and Methods}

Kaupapa Māori methodology informs this research where Māori philosophies and principles underpin and guide the study in order to generate explanations of tūhono and tūhonotanga. The selected methods are consistent with talking-and therapy-based methods. To understand the nature in which mokopuna Māori become securely attached to whānau is to appreciate how whānau living arrangements are constellated, with a focus on Māori social caregiving arrangements.

The potential whānau constellations are inclusive of both non-Māori caregivers and parents who identify as Māori through whakapapa. This inclusion does not detract from the distinction that this Kaupapa Māori research is controlled by Māori for the empowerment of Mãori. Bishop (2010) has argued that Te Tiriti o Waitangi (the Treaty of Waitangi) provides the space to enable this to happen. The aim is to explore traditional and contemporary notions of whānau Māori where healthy emotional bonds are fostered and secure whānau attachments are promoted. An advisory rōpū (group) was established to provide guidance and strengthen aspects of the research as it unfolds. The Māori and Indigenous advisory rōpū meet kanohi-ki-te-kanohi (face-to-face) or by video-conferencing and meetings to ensure consistency with the research design and Māori processes. The advisory rōpū bring specialist Māori knowledge such as te reo me ōnā tikanga, Indigenous research skills, specialist child focus expertise, trauma and attachment theory knowledge and training, Māori community development and management skills, social justice advocacy and Indigenous educational curriculum design skills. Together the advisory rōpu bring multidimensional skill sets to strengthen the study and ensure research rigour, peer review assistance, and thoroughness throughout the research process.

Kaupapa Māori methodology underpins this qualitative research to ensure consistency with a Māori worldview. Embedded in Kaupapa Māori methodology is an appreciation for the nature in which whānau relationships are mediated. Importantly, whānau ascertain and identify key members of a whānau system and the people who help to whakatipu (nurture/ raise) healthy mokopuna Māori.

\section{Whakapapa: Genealogy}

Whakapapa (genealogy) is pivotal to the Tūhono Māori study and appreciates that attachments are both interpersonal and extra-personal (Fleming, 2018). Whakapapa recounts our history, our ancestors, our evolution from the cosmos and the omnipotent atua (gods) of our ecological system. To speak about attachment from a Māori perspective is to first discuss whakapapa and the philosophical origins of our existence, to provide the context for the research methodology and methods (ontology). The Māori worldview is dynamic, where an interconnected interdependent relationship exists between the cosmos, the eco system and 
human existence. Papatūānuku (earth mother) and Ranginui (sky father) are the primal parents of all life forms and the natural environment where everything in the world grows, develops and derives sustenance. The children of Papatūānuku and Ranginui are many and varied, and all living species, natural resources and atmospheric elements co-exist as an interactive constellation of family relationships. These relationships are mediated through tikanga (values) that inform important decision-making and actions taken. Tikanga Māori (Māori values) have developed over time to manage social behaviours and interactions with the environment. Ruru (2005) discusses Indigenous family law and the relationship between people and the natural world as a way of life,

... between: people and gods; different groups of people; and people and everything in the surrounding world. Integral values thus include whakapapa (genealogy), whanaungatanga (family relationships), mana (authority), mauri (spiritual life-principles/life force), tapu (sacredness), rāhui (prohibition or conservation) and manaaki (hospitality). (2018, p. 216)

Justice Eddie Durie's (2005) accounts of whakapapa (genealogy) as a traditional knowledge system illustrated the fundamental philosophical underpinnings for Mãori which are interconnected to "a spiritual comprehension of eternity" (p.48). He asserted, "In the context of whakapapa, one is forever a living part of an ever-flowing stream that makes the past and future an intimate part of the present reality" (p. 48 ). It is not possible to investigate tūhono and tūhonotanga without an appreciation for whakapapa and whānau.

\section{Research Participants}

The research is designed to engage with whakapapa and kaupapa whānau with lived and diverse realities (M. Durie, 2004). Whānau Māori are constellated by a number of characteristics, including mixed-ethnicity marriages or partnerships, single parents, same sex couples, blended whānau arrangements, whāngai (foster) parents, and whānau hauā (disabled) to include our turi (hearing impaired) and kāpō (sight impaired) whānau, as well as grandparents raising mokopuna. There is evidence to suggest that the number of grandparents raising mokopuna is steadily growing in recent decades (C. Smith, 2008). Further considerations include the provision for non-Māori participants to join this research project. The whānau configurations reflect the diversity of contemporary whānau composition and the child-rearing environments that mokopuna Māori grow up in.

The whānau constellations include whānau members from age 16-80+ years who have the ability to give informed consent. This is to ensure research participants meet the current legal requirements to provide the day-to-day care for dependent children. The study further requires all potential participants be safe caregivers.

The research takes a multi-generational approach to engage with a Māori-constructed whānau system where mokopuna Māori are located within whakapapa whānau, whāngai whānau, kaupapa whānau and whānau-hapū (see figure 2) to capture the lived realities of a dynamic Māori whanau system (Hall, 2013). Given this dynamic arrangement, the research refers to each whānau participant group as a whānau constellation. 


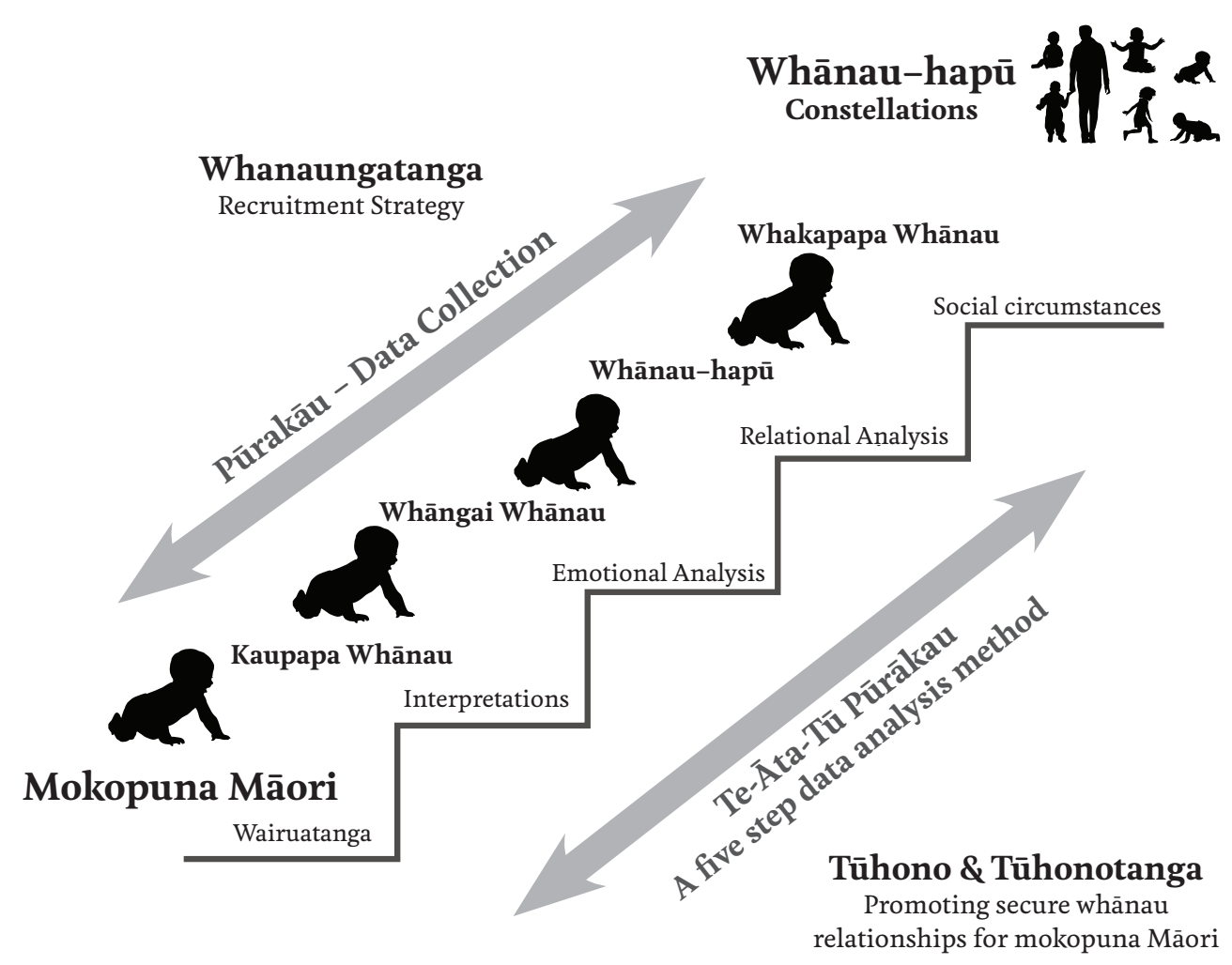

FIGURE 2. OVERVIEW OF RESEARCH DESIGN AND METHODS

\section{Whanaungatanga: Recruitment Method}

Whanaungatanga (extended relationships) is a method used to establish relationship through existing relationships. Whanaungatanga is a network of relationships that operate at both a personal and professional level and is utilised as the main strategy for identifying and engaging with potential research participants. This research seeks to engage with key informants with requisite skills, knowledge and mātauranga Māori that relate to the concepts tūhono and tūhonotanga. Participants were recruited initially from professional Māori networks and whānau-hapū-iwi networks. The primary research investigator engaged the support of kaumātua-kuia (elders) when necessary to assist in upholding cultural requisites such as te reo and tikanga-kawa (protocols) during the whanaungatanga recruitment stage and again when research findings were reported back to whānau, hapū, and iwi. The research investigators will be cognisant that whānau are best positioned to identify suitable research participants, and will engage with whānau to determine the nature in which the whānau system is constellated in preparation for proposed interviews. The whanaungatanga recruitment strategy is used in this study to identify potential key informant, kaumātua-kuia, and whānau-hapū constellations. 


\section{Pūrākau: Data Collection Method}

Pūrākau (narratives) provide the main method of data collection, where family knowledge and traditional knowledge is gathered from key informants, elders and whānau-hapu constellations. The research includes pūrākau as an Indigenous narrative method to gather important data to generate a new contemporary theory on secure whānau attachments. Pūrākau as a research method enables whānau Māori to tell their lived experiences in a nononsense pragmatic way. Critics of Indigenous narrative approaches have frequently denigrated the validity of storytelling as no more than a myth-making process. Dr Ranginui Walker (1975) discussed the importance of ensuring that contemporary society fully appreciates the principles embedded in the "myth-messages" portrayed in Māori mythology, to ensure they are made clear and easily understood. He noted:

The validity of myths was not questioned by the Mãori until the post-Christian era when they were displaced by the mythology of a new culture. Today 'kōrero pūrākau' has the same negative connotation of untruth as it is only a myth. This is unfortunate, since an analysis of Māori myths will show that even today Māori will respond to the myth messages and cultural imperatives embedded in their mythology. The myth-messages now need to be spelled out to the modern Māori. (p. 20)

Walker (1975) also raised the issue of analysis and clarity to ensure that the messages embedded within the "myth-message" are not reduced to a set of fables and tales that minimises the importance of the real message to be revealed. The data analysis method Teàta-tu Pūrākau is critical to ensure that the mist is removed from the myth so that the significance of each pūrākau is revealed.

Bell (2006) asserted the legitimacy of pūrākau as a concept originating from Te Ao Tawhito (the traditional world) and therefore substantiated pūrākau as a Māori pedagogy. Lee (2009) attested to the versatility of pūrākau, arguing for the applicability within Kaupapa Māori. Karena-Waretini (2012), Cherrington (2009), Hall (2005) and Elkington (2006) promote pūrākau in the psychology, psychotherapy and counselling disciplines as a culturally appropriate modality when working with Māori tamariki and whānau. Pūrākau is a traditional narrative method inherent to Māori where the flow of information is transmitted between people and across generations. It is therefore suited to the social sciences and qualitative methods. Pūrākau were and remain an important aspect of the Māori language, providing an essential mechanism for the communication of day-to-day affairs concerning whānau, hapū, and iwi. The research utilises pūrākau as a data collection method during the interview process with key informants, kaumātua-kuia and whānauhapū. Pūrākau provide a platform for whānau to relay their personal experiences and to convey their unique narratives. Pūrākau are the significant and incredible consequential stories that are conveyed through körero (talk) where all the voice intonations, nuances, body language, and behaviours are essential to the telling of the story. 


\section{Te-āta-tu Pūrākau: A Five Step Data Analysis Method}

Te-āta-tu Pūrākau (Mikahere-Hall, 2017) arose out of $\mathrm{PhD}$ research and was developed as a new indigenous Māori data analysis method that involves five levels of analysis. The levels of analysis can be likened to the poutama (steps) seen in the woven tukutuku panels frequently adorning Māori carved meeting houses. The interesting characteristic of poutama is the ability to both ascend and descend, enabling the analysis to capture the storyteller's inclination to move through different aspects of their pūrākau. Te-āta-tu Pūrākau contributes to the continuing development of Māori research methods, particularly within the clinical and social services sector as a construct for critical reflection and interpretation. Te-āta-tu Pūrākau is an approach that has similarities with narrative therapy, narrative counselling and narrative analysis. Chase (2005) explained the roots of narrative analysis through the Chicago School tradition:

The tradition of narrative analysis has typically been one that focuses on individual stories, life histories, autobiographies and the lived experiences of particular individuals whose stories serve as the bulk of the empirical material for a study. Known as the 'Chicago School', the tradition allowed the narrative in many ways to speak for itself, but as the field has developed, methods are being pursued that allow for attention to dimensions across narratives, while at the same time not losing the richness of the various dimensions within narratives. (p. 30)

Narrative approaches are favoured methods employed by Indigenous qualitative researchers (Atkinson, 2007; Geia, Hayes, \& Usher, 2013; Sium \& Ritskes, 2013).

Together pūrākau and Te-āta-tu Pūrākau are connected and derive from a Māori spiritual belief system as discussed previously; this is one of the key differences for whānau Māori in the narrative exchange. The analysis includes a wairua dimension that enables whannau Māori the opportunity to speak to their personal experiences from a belief system both deeply held and shared within a Māori world view. As I have noted elsewhere (MikahereHall, 2017),

Te-āta-tu refers to the dawning of a new day. Āta is often referred to as early morning or the space between darkness and light. Âta indicates that something new is about to emerge; a movement from one state into another, as in transforming from night into day. The transformation from night to day is captured in mātauranga Māori and frequently conveyed in eloquent Māori oratory and speechmaking as "ki te wheiao ki te ao mārama e." Wheiao means the place between the world of darkness and the world of light, while mārama indicates the transitioning period toward the world of light. (p. 7)

Te-āta-tu Pūrākau is the 5-step analysis process that reveals the key messages relayed in the purākau. The analysis pays attention to pūrākau where wairua (spirit) or wairuatanga (spirituality) is mentioned. This is where whānau convey their beliefs about their experiences and how they make sense of what happened for them. 


\section{Poutama: Five Steps}

1. The first linear level focuses on the basic structure of the pūrākau that includes the social circumstances of the whānau.

2. The second level focuses on the important whānau relationships, where spatial, sequential and historical factors emerge, such as whakapapa connections.

3. The third level of analysis is interested in the emotional aspects of the purākau. Subjective and inter-personal experiences of the emotional bonds created between whānau and their tamariki and mokopuna.

4. The fourth level concentrates on the analysis and interpretations made by the research team based on the previous levels of analysis.

5. The fifth level focuses on wairua dimensions that are conveyed by the whannau participant's pūrākau. It acknowledges and accepts the importance of wairuatanga for whānau without the unnecessary and often unhelpful judgements of critical spectators.

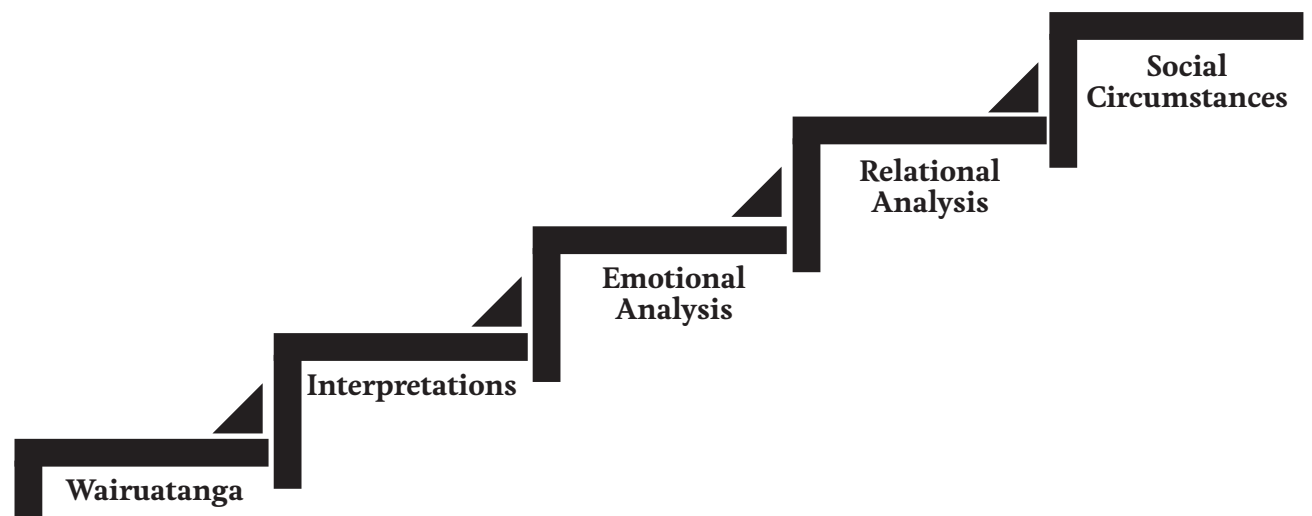

Figure 3. Te-āta-tu Pūrākau five step analysis method

Together Pūrākau and Te-āta-tu Pūrākau will provide the explanations that arise from this research study to provide a foundational theory of attachment through an Indigenous Māori lens.

\section{Concluding Remarks}

The overall aim of this study is to develop theory that will contribute to the development of effective Māori and Indigenous prevention and intervention strategies. The purpose is to prevent traumatic experiences for mokopuna Māori and to engage in treatment and healing that responds appropriately when trauma occurs. The study is invested in Kaupapa Māori research methodology in an attempt to change the circumstances for vulnerable tamariki and mokopuna Māori. Tūhono Māori is a qualitative relational study with potential advantages for tamariki and mokopuna Māori and whānau in all age groups. Tūhono Māori 
has a decolonising agenda to promote a secure sense of Māori identity and attachment, and a workforce mobilisation agenda to effect transformation by investing in practitioner change to better equip the health workforce to respond more effectively to Māori health priorities. Importantly, this research also has an Indigenous healing agenda to transform Māori suffering from surviving to thriving. Tūhono Māori shifts the focus away from what makes people fail to what makes them successful.

\section{Glossary}

Aotearoa

aroha

hapū

iwi

kaitiakitanga

kaumātua-kuia

Kaupapa Māori

kaupapa whānau

mana

manaakitanga

mātauranga Māori

mokopuna

Pākehā

pūrākau

rōpū

tamaiti

tamariki

te reo Māori

te reo Māori me ōnā tikanga

tikanga

tūhono

tūhonotanga

wairua

whakapapa

whakapapa whānau

whāngai

whānau

whanaungatanga
Indigenous pre-European name for New Zealand love and commitment, compassion, positive regard extended family (grandparents, aunties, uncles, cousins) confederation of kin group

guardianship, stewardship

elders

an analytical approach to research that is connected to Māori philosophy and principles

family, friends and colleagues who support whānau towards a common goal

authority, prestige

care, hospitality, regard for others

Māori knowledge

grandchild

New Zealander of European descent

narratives, stories

group

child

children

Māori language

the Māori language and values

correct customs and procedures

attach, bond

connection, connectedness, attachment

spirit

genealogy, genealogical table, lineage, descent, layers

family connected by genealogy

to feed, nourish, foster, adopt, raise, nurture

immediate family and extended family

extended family relationships 


\section{References}

Atkinson, J. (2007). Indigenous approaches to child abuse. In J. Altman \& M. Hinkson (Eds.), Coercive reconciliation: Stabilise, normalise, exit Aboriginal Australia (pp.151-162). Melbourne, Australia: Arena Publications.

Bell, H. (2006). Exiting the matrix: Colonisation, decolonisation and social work in Aotearoa. (Unpublished Master's thesis). Massey University, Palmerston North, New Zealand.

Bishop, R. (2010). Effective teaching for Indigenous and minoritized students. Procedia-Social and Behavioural Sciences, 7, 57-62.

Chase, S. E. (2005). Narrative enquiry: Multiple lenses, approaches, voices. In N. K. Denzin \& Y.S. Lincoln (Eds.), The Sage book of qualitative research. San Francisco, CA: Jossey-Bass.

Cherrington, L. (2009). Te hohounga: Mai i te tirohanga Māori - The process of reconciliation: Towards a Māori view - The delivery of conduct problem services to Māori. Wellington, New Zealand: Ministry of Social Development.

Cram, F., \& Kennedy, V. (2010). Researching with whānau collectives. Mai Review, 3, 1-12.

Durie, E. T. (2005). Māori research, ethics and law. In L. T. Smith \& M. Walker (Eds.), Proceedings of Tikanga Rangahau Mātauranga Tuku Iho: Traditional Knowledge and Research Ethics Conference, 2004 (pp. 44-53). Auckland, New Zealand: Ngā Pae oTe Māramatanga.

Durie, M. H. (1995). Te hoe nuku roa framework: A Māori identity measure. The Journal of the Polynesian Society, 104(4), 461-470.

Durie, M. (2004). An indigenous model of health promotion. Health Promotion Journal of Australia, 15(3), 181-185.

Durie, M. (2006). Measuring Māori wellbeing. Paper presented at the New Zealand Treasury Guest Lecture Series, Wellington.

Eketone, A. (2008). Theoretical underpinnings of Kaupapa Maori directed practice. Mai Review, 1. Elkington, J. (2006). The pūrākau model: A counselling training resource for Te Whiuwhiu o Te Hau Māori Counselling Programme. Hamilton, New Zealand: Centre for Health and Social Practice, Waikato Institute of Technology.

Fleming, A. H. (2018). Ngā Tāpiritanga. Ata: Journal of Psychotherapy Aotearoa New Zealand, 22(1), 23-36. https://doi.org/10.9791/ajpanz.2018.03

Geia, L. K., Hayes, B., \& Usher, K. (2013). Yarning/Aboriginal storytelling: Towards an understanding of an Indigenous perspective and its implications for research practice. Contemporary Nurse, 46(1), 13-17.

Hall, A. (2005). Cultural identity in the child psychotherapy environment: A Mãori perspective. (Unpublished Master's thesis). Auckland University of Technology, New Zealand.

Hall, A. (2013). Ko Rangitoto, Ko Waitematā: Cultural landmarks for the integration of a Māori indigenous psychotherapy in Aotearoa. Ata: Journal of Psychotherapy Aotearoa New Zealand, 17(2), 139-157. https://doi.org/10.9791/ajpanz.2013.14

Hall, A. (2015). An indigenous Kaupapa Māori approach: Mother's experiences of partner violence and the nurturing of affectional bonds with tamariki (Doctoral dissertation). Auckland University of Technology, New Zealand.

Hudson, M., Milne, M., Reynolds, P., Russell, K., \& Smith, B. (2010). Te Ara Tika - Guidelines for Māori research ethics: A framework for researchers and ethics committee members. Auckland, New Zealand: Health Research Council of New Zealand.

Karena-Waretini, R. (2012). Takitoru: From parallel to partnership. A ritual of engagement based 
on Te Tiriti o Waitangi for implementing safe cultural practice in Māori counselling and social science. MAI Journal, 1(1), 61-75.

Lawson-Te Aho, K. (2010). Definitions of whānau: A review of selected literature. The Hub. Retrieved from https://thehub.sia.govt.nz/resources/definitions-of-whanau-a-review-ofselected-literature/

Lee, J. (2009). Decolonising Māori narratives: Pūrākau as a method. Mai Review, 2, 1-12.

Louis, R. P. (2007). Can you hear us now? Voices from the margin: Using indigenous methodologies in geographic research. Geographical research, 45(2), 130-139.

Mikahere-Hall, A. (2017). Constructing research from an indigenous Kaupapa Māori perspective: An example of decolonising research. Psychotherapy and Politics International, 15(3). https://doi. org/10.1002/ppi.1428

Moeke-Pickering, T. (1996). Māori identity within whānau: A review of the literature. Hamilton, New Zealand: University of Waikato.

Pohatu, T. W. (2013). Ata: Growing respectful relationships. Ata: Journal of Psychotherapy Aotearoa New Zealand, 17(1), 13-26. https://doi.org/10.9791/ajpanz.2013.02

Ruru, J. (2018). Listening to Papatūānuku: a call to reform water law. Journal of the Royal Society of New Zealand, 48(2-3), 215-224.

Ruru, J. (2005). Indigenous peoples and family law: Issues in Aotearoa/New Zealand. International Journal of Law, Policy and the Family, 19(3), 327-345.

Ruwhiu, L. A., Ashby, W., Erueti, H., Halliday, A., Horne, H., \& Paikea, P. (2009). A Mana Tāne echo on hope: Dispelling the illusion of whanau violence - Taitokerau Tāne Māori speak out. Whāngarei, New Zealand: Amokura Family Violence Prevention Consortium.

Sherwood, J. (2010). Do no harm: Decolonising Aboriginal health research. (Doctoral thesis). University of New South Wales, Sydney, Australia.

Sium, A., \& Ritskes, E. (2013). Speaking truth to power: Indigenous storytelling as an act of living resistance. Decolonization: Indigeneity, education e Society, 2(1), I-X.

Smith, C. (2008). Māori grandparents: Raising mokopuna fulltime. In J. S. Te Rito \& S. M. Healy (Eds.). Proceedings of the Traditional Knowledge Conference 2008 Te Tatau Pounamu: The Greenstone Door. Traditional knowledge and gateways to balanced relationships, pp. 261-265. Auckland NZ: Ngā Pae o Te Maramatanga.

Smith, G. H. (2012). The politics of reforming Maori education: The transforming potential of Kura Kaupapa Maori. In H. Lauder \& C. Wylie (Eds.), Towards successful schooling, pp. 73-87. London: Routledge.

Smith, L. T. (2013). Decolonizing methodologies: Research and indigenous peoples. London, England: Zed Books.

Smith, L. T., Maxwell, T. K., Puke, H., \& Temara, P. (2016). Indigenous knowledge, methodology and mayhem: What is the role of methodology in producing Indigenous insights? A discussion from mātauranga Māori.

Statistics New Zealand (2013). Te Kupenga 2013. Retrieved from http://archive.stats.govt.nz/ browse_for_stats/people_and_communities/maori/kei-te-pewhea-to-whanau-2012/newapproach-measuring-whanau.aspx

Walker, R. (1975). The relevance of Mãori myth and tradition. In M. King (Ed.), Te Ao Hurihuri/The world moves on: Aspects of Māoritanga. Auckland, New Zealand: Longman Paul. 


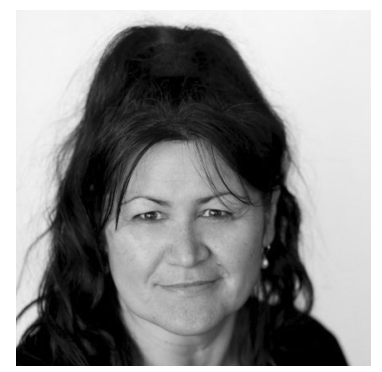

Alayne Mikahere-Hall is kinship affiliated with Ngāti Whatua, Te Rarawa and Tainui. Alayne is a post-doctoral research fellow with Taupua Waiora Research Centre, Auckland University of Technology. She is the lead investigator on the Tūhono Māori research project, funded by the Health Research Council of New Zealand. Tūhono Māori is an investigation into a Māori understanding of secure attachment. Alayne engages with Indigenous methodologies and Kaupapa Māori methods and theory. She has an interest in developing evidence-based Māori and Indigenous therapeutic interventions to develop theories concerning complex trauma. Alayne is also an investigator on the E Tū Wāhine, E Tū Whānau study, aimed at reducing the harmful effects of violence against women and families and to break cycles of complex whakapapa trauma (inter-generational family trauma). She is a current member of the Health Quality and Safety Commission Child Youth Mortality Review Committee and Nga Pou Arawhenua Mortality Review Committee. Alayne is a Registered Psychotherapist, a member of the New Zealand Association of Psychotherapists (NZAP) and a founding member of Waka Oranga - National Collective of Māori Psychotherapy Practitioners (NCMPP).Contact details: alhall@aut.ac.nz. 